\title{
The pro-apoptotic K-Ras 4A proto-oncoprotein does not affect tumorigenesis in the $\mathrm{Apc} \mathrm{Min}^{++}$mouse small intestine Charles E Patek1, Mark J Arends², Lorraine Rose ${ }^{1,6}$, Feijun Luo ${ }^{2}$, Marion Walker ${ }^{1,5}$, Paul S Devenney ${ }^{1,4}$, Rachel L Berry ${ }^{1,4}$, Nicola J Lawrence ${ }^{1,7}$, Rachel A Ridgway ${ }^{3}$, Owen J Sansom ${ }^{3}$ and Martin L Hooper*1
}

Address: ${ }^{1}$ Sir Alastair Currie Cancer Research UK Laboratories, Molecular Medicine Centre, The University of Edinburgh, Western General Hospital, Crewe Road, Edinburgh, EH4 2XU, UK, ²Department of Pathology, The University of Cambridge, Addenbrooke's Hospital, Hills Road, Cambridge, CB2 2QQ, UK, ${ }^{3}$ The Beatson Institute for Cancer Research, Garscube Estate, Switchback Road, Glasgow, G61 1BD, UK, Current Addresses: ${ }^{4}$ Comparative and Developmental Genetics, MRC Human Genetics Unit, Western General Hospital, Crewe Road, Edinburgh, EH4 2XU, UK, ${ }^{5}$ Division of Oncology, The University of Edinburgh, Western General Hospital, Crewe Road, Edinburgh, ,EH4 2XU, UK, ${ }^{6}$ Rheumatic Diseases Unit, Molecular Medicine Centre, The University of Edinburgh, Western General Hospital, Crewe Road, Edinburgh, EH4 2XU, UK and ${ }^{7}$ Department of Genetics, Erasmus University Medical Centre, Dr. Molewaterplein, Rotterdam, 3015 GE, The Netherlands

Email: Charles E Patek - charles.patek@hotmail.com; Mark J Arends - mja40@cam.ac.uk; Lorraine Rose - lrose@staffmail.ed.ac.uk; Feijun Luo - fl239@cam.ac.uk; Marion Walker - Marion.Walker@ed.ac.uk; Paul S Devenney - pauldev@hgu.mrc.ac.uk; Rachel L Berry - rberry@hgu.mrc.ac.uk; Nicola J Lawrence - n.lawrence@erasmusmc.nl; Rachel A Ridgway - r.ridgway@beatson.gla.ac.uk; Owen J Sansom - o.sansom@beatson.gla.ac.uk; Martin L Hooper* - m.hooper@ed.ac.uk

* Corresponding author

Published: 13 June 2008

BMC Gastroenterology 2008, 8:24 doi:10.1 |86/I47|-230X-8-24

This article is available from: http://www.biomedcentral.com/I47I-230X/8/24

(C) 2008 Patek et al; licensee BioMed Central Ltd.

This is an Open Access article distributed under the terms of the Creative Commons Attribution License (http://creativecommons.org/licenses/by/2.0), which permits unrestricted use, distribution, and reproduction in any medium, provided the original work is properly cited.

\begin{abstract}
Background: Alterations in gene splicing occur in human sporadic colorectal cancer (CRC) and may contribute to tumour progression. The K-ras proto-oncogene encodes two splice variants, $\mathrm{K}$ ras $4 \mathrm{~A}$ and $4 \mathrm{~B}$, and $\mathrm{K}$-ras activating mutations which jointly affect both isoforms are prevalent in CRC. Past studies have established that splicing of both the K-ras oncogene and proto-oncogene is altered in CRC in favour of K-ras 4B. The present study addressed whether the K-Ras 4A protooncoprotein can suppress tumour development in the absence of its oncogenic allele, utilising the $\mathrm{ApC}_{\mathrm{Min} /+}(\mathrm{Min})$ mouse that spontaneously develops intestinal tumours that do not harbour K-ras activating mutations, and the K-ras $\mathrm{tm}_{\mathrm{m}} 4 \mathrm{~A} / \mathrm{tm} \triangle 4 \mathrm{~A}$ mouse that can express the $\mathrm{K}$-ras $4 \mathrm{~B}$ splice variant only. By this means tumorigenesis in the small intestine was compared between $\mathrm{ApC} \mathrm{Min} /+, \mathrm{K}-\mathrm{ras}^{+/+}$ and $A p c^{\mathrm{Min} /+}$, K-ras ${ }^{\mathrm{tm}} \triangle 4 \mathrm{~A} / \mathrm{tm} \triangle 4 \mathrm{~A}$ mice that can, and cannot, express the $\mathrm{K}$-ras $4 \mathrm{~A}$ proto-oncoprotein respectively.
\end{abstract}

Methods: The relative levels of expression of the K-ras splice variants in normal small intestine and small intestinal tumours were quantified by real-time RT-qPCR analysis. Inbred (C57BL/6) $A p c^{\mathrm{Min} /+}, \mathrm{K}-$ ras $^{+/+}$and $A p \mathrm{C}^{\mathrm{Min} /+}, \mathrm{K}-\mathrm{ras}^{\mathrm{tm}} \Delta 4 \mathrm{~A} / \mathrm{tm} \Delta 4 \mathrm{~A}$ mice were generated and the genotypes confirmed by PCR analysis. Survival of stocks was compared by the Mantel-Haenszel test, and tumour number and area compared by Student's $t$-test in outwardly healthy mice at approximately 106 and 152 days of age. DNA sequencing of codons 12,13 and 61 was performed to confirm the intestinal tumours did not harbour a K-ras activating mutation.

Results: The K-ras 4A transcript accounted for about $50 \%$ of $\mathrm{K}$-ras expressed in the small intestine of both wild-type and Min mice. Tumours in the small intestine of Min mice showed increased levels 
of K-ras 4B transcript expression, but no appreciable change in K-ras 4A transcript levels. No Kras activating mutations were detected in 27 intestinal tumours derived from Min and compound mutant Min mice. K-Ras 4A deficiency did not affect mouse survival, or tumour number, size or histopathology.

Conclusion: The K-Ras 4A proto-oncoprotein does not exhibit tumour suppressor activity in the small intestine, even though the K-ras $4 \mathrm{~A} / 4 \mathrm{~B}$ ratio is reduced in adenomas lacking K-ras activating mutations.

\section{Background}

The development of sporadic colorectal cancer (CRC) involves genetic and epigenetic changes, including allelic losses in specific chromosomal arms, mutations of oncogenes, tumour suppressor genes and mismatch repair genes, micro-satellite instability, and methylation changes in gene promoters [reviewed [1]]. Additionally, CRC is frequently associated with altered splicing of tumour suppressor genes, and genes encoding enzymes, growth factors, cytoskeletal and cell adhesion proteins, hormone and growth factor receptors, and transcription factors [see [2-5]]. Importantly, since different splice variants of a given gene can have different or even antagonistic effects on diverse cellular functions, including apoptosis, proliferation, differentiation, angiogenesis and cell motility, a change in the splice variant ratio may actively contribute to tumour progression. Indeed, positive selection for splice variants that encode isoforms with a selective advantage in tumour progression is of potential diagnostic value and could provide therapeutic targets.

Ras proteins are low molecular weight ( $21 \mathrm{kD})$ GTPases which cycle between the GDP-bound (inactive) and the GTP-bound (active) state at the plasma membrane, and thereby regulate cell growth, apoptosis, motility and differentiation. K-ras activating point mutations occur in about $50 \%$ of human sporadic CRC cases and act by stabilising the active GTP-bound configuration, and so promote cellular transformation by constitutive activation of downstream effector pathways, including Raf kinases, phosphatidylinositol 3-kinases (PI3-K), and RalGDS family members [reviewed [6]]. K-ras activating mutations play a key role in tumour progression and metastasis in CRC by regulating angiogenesis and protease expression, and cell polarity, adhesion and motility [see [7-9]]. The Kras gene encodes two splice variants, K-ras $4 \mathrm{~A}$ and $4 \mathrm{~B}$, and activating mutations that usually arise at codons 12,13 or 61, jointly affect both isoforms [reviewed [6]]. Importantly, since K-Ras oncoproteins differentially promote transformation, cell migration, and anchorage-independent growth, they most probably act in a cooperative manner to drive neoplastic progression [10]. The ratio of the $\mathrm{K}$-ras $4 \mathrm{~A} / 4 \mathrm{~B}$ splice variants is reduced in human sporadic CRC in both primary adenocarcinomas and colon cancer cell lines that harbour K-ras activating mutations, includ- ing homozygous mutations $[11,12]$. Since mutationally activated K-Ras $4 \mathrm{~B}$ has an anti-apoptotic action $[13,14]$ and, unlike K-Ras $4 \mathrm{~A}$, can promote cell migration [10], and $\mathrm{K}$-Ras $4 \mathrm{~B}$ can drive expression of matrix metalloproteinase 2 (MMP-2) which specifically cleaves type IV collagen, and is involved in cell detachment and migration [15], the altered splicing of the K-ras oncogene in CRC in favour of K-ras 4B could contribute to neoplastic progression by enabling the survival of cells with DNA damage and facilitating tumour invasion and, ultimately, metastasis. Indeed, tumour growth and metastasis in human CRC is linked with increased expression of MMP-2 [see [7]]. However, the finding that the $\mathrm{K}-\mathrm{ras} 4 \mathrm{~A} / 4 \mathrm{~B}$ ratio is also reduced in CRC cell lines that lack K-ras activating mutations raises the possibility that a regulated switch in alternative splicing of the K-ras proto-oncogene may also have a causal role in tumour progression [12]. The mechanism could involve increased expression of MMP-2 (see above), and/or reduced apoptosis given that the K-Ras 4A protooncoprotein exerts a pro-apoptotic action in mouse intestine following etoposide-induced DNA damage, and evidence that the K-Ras proto-oncoproteins have antagonistic effects on apoptosis in embryonic stem (ES) cells: Ras 4A promotes, whereas K-Ras 4B inhibits, apoptosis [16]. Further, while K-Ras $4 \mathrm{~B}$, and probably K-Ras $4 \mathrm{~A}$, promote $\mathrm{ES}$ cell differentiation following withdrawal of leukaemia inhibitory factor [16] it is unlikely they do so with similar efficiency since the Raf/MAPK pathway regulates stem cell differentiation [reviewed [17]] and K-Ras $4 \mathrm{~A}$ and $4 \mathrm{~B}$ differ in their ability to activate Raf-1 [10]. Therefore, in accordance with the 'stem cell model' for cancer formation we proposed that a change in the ratio of K-Ras proto-oncoproteins may further contribute to neoplastic progression by perturbing stem cell differentiation [see [12]]. Thus, altered splicing of the K-ras protooncogene could drive tumour progression in sporadic CRC by promoting MMP-2 expression, and inappropriate stem cell survival and self-renewal.

To address the hypothesis that alteration in the ratio of the $\mathrm{K}$-Ras proto-oncoproteins in favour of K-Ras $4 \mathrm{~B}$ can affect tumour formation in the small intestine in the absence of K-ras activating mutations, K-ras ${ }^{\mathrm{tm}} \triangle 4 \mathrm{~A} / \mathrm{tm} \Delta 4 \mathrm{~A}$ mice, which express the K-ras 4B splice variant only [18], were crossed with $A p c^{\mathrm{Min} /+}$ (Min) mice. The latter mice harbour a heter- 
ozygous germ-line nonsense mutation in the Apc (adenomatous polyposis coli) tumour suppressor gene, and are predisposed to developing multiple intestinal tumours initiated by loss of the wild-type $A p c$ allele [reviewed [19]]. By this means tumorigenesis in the small intestine was compared between $A p c^{\mathrm{Min} /+}, \mathrm{K}_{-} \mathrm{ras}^{+/+}$and $A p c^{\mathrm{Min} /+}, \mathrm{K}-$

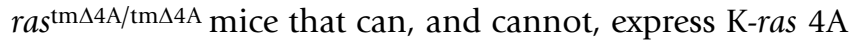
respectively. This approach was selected since K-ras ${ }^{\mathrm{tm} \Delta 4 \mathrm{~A} /}$ $\operatorname{tm} \triangle 4 \mathrm{~A}$ mice are healthy $[16,18]$, intestinal tumours in Min mice do not harbour K-ras activating mutations [20], and K-Ras 4A deficiency does not affect K-ras 4B expression in the small intestine [16] where, importantly, most (>95\%) intestinal tumours form in Min mice [reviewed [19]]. Thus, the effect of K-Ras $4 \mathrm{~A}$ on tumorigenesis can be examined in the absence both of its oncogenic allele and of alteration in K-ras 4B expression as a consequence of $\mathrm{K}$ Ras 4A deficiency.

\section{Methods \\ Mice}

All animal work was carried out using procedures approved by the ethical panel of the University of Edinburgh and licensed by the Home Office (Project licence PPL60/3433). Inbred $\mathrm{Apc}^{\mathrm{Min} /+}$ mice $(\mathrm{C} 57 \mathrm{BL} / 6)$ were obtained from The Jackson Laboratory (Bar Harbor,

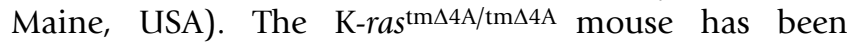
reported previously [18]. Since penetrance of the $A p c^{\mathrm{Min}}$ mutation is affected by genetic background, the K-ras ${ }^{\mathrm{tm}} \Delta 4 \mathrm{~A}$ allele on a F1(129/Ola $\times$ C57BL/6) background was backcrossed for a further 8 generations on to the susceptible

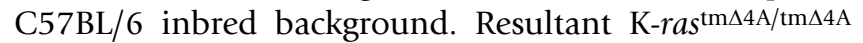
mice were confirmed as congenic for the C57BL/6 Pla $2 g 2 a$ allele (Mom-1) by PCR as described previously [21]. Inbred $\mathrm{Apc}^{\mathrm{Min} /+}, \mathrm{K}_{-\mathrm{ras}^{+/+}} \times \mathrm{Apc}^{+/+}, \mathrm{K}_{-\mathrm{ras}^{\mathrm{tm}} \Delta 4 \mathrm{~A} / \mathrm{tm} \Delta 4 \mathrm{~A}}$ crosses generated $A p c^{\mathrm{Min} /+}$, K-ras $\mathrm{tm}^{\mathrm{tm}} 4 \mathrm{~A} /+$ and $A p c^{+/+}$, K-ras ${ }^{\mathrm{tm} \Delta 4 \mathrm{~A} /+}$ mice. Male $A p c^{\mathrm{Min} /+}, \mathrm{K}-\mathrm{ras}^{\mathrm{tm} \Delta 4 \mathrm{~A} /+}$ mice were crossed with female $A p c^{+/+}, \mathrm{K}-\mathrm{ras}^{\mathrm{tm} \Delta 4 \mathrm{~A} /+}$ mice to generate informative $A p c^{\mathrm{Min} /+}, \mathrm{K}-\mathrm{ras}^{+/+}$and $A p c^{\mathrm{Min} /+}, \mathrm{K}-r a s^{\mathrm{tm} \Delta 4 \mathrm{~A} / \mathrm{tm} \Delta 4 \mathrm{~A}}$ offspring. Mice heterozygous for the $A p c^{\text {Min }}$ allele were identified by PCR as described previously that generates a wild-type (123 bp) and mutant $A p c^{\mathrm{Min}}$ (144 bp) band [22]. The K-ras genotype was determined using primers that amplify K-ras exon $4 \mathrm{~A}$, and primers that identify the mutant $\mathrm{K}-r a s^{\mathrm{tm} \Delta 4 \mathrm{~A}}$ allele by amplifying the neo cassette which replaces K-ras exon $4 \mathrm{~A}$, that generate $72 \mathrm{bp}$ and 206 bp bands respectively [18]. The genotyping of mice is summarised in Table 1. Survival curves for $A p c^{\mathrm{Min} /+}, \mathrm{K}_{-} \mathrm{ras}^{+/+}$and $A p c^{\mathrm{Min} /+}$, K-ras ${ }^{\mathrm{tm}} \Delta 4 \mathrm{~A} / \mathrm{tm} \Delta 4 \mathrm{~A}$ mice were compared using the MantelHaenszel test [23]. Mice were culled immediately on showing signs of intestinal neoplasia, including anaemia, pale feet, hunching and/or swollen abdomen. A small number of mice ( 3 male and 4 female $A p c^{\mathrm{Min} /+}, \mathrm{K}-\mathrm{ras}^{+/+}$

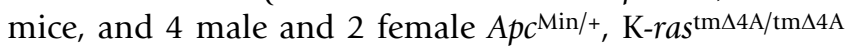
mice) with rectal prolapse, which were immediately culled, and also mice randomly withdrawn for tumour counts were treated as censored observations [23]. Reclassification of mice with prolapse as uncensored observations did not affect any of the conclusions of the study.

\section{Histology}

Mice were killed by $\mathrm{CO}_{2}$ asphyxiation and the small intestine removed, flushed with phosphate buffered saline, opened lengthwise, and mounted en face. Following fixation for 4 hours in methacarn (4 volumes methanol, 2 volumes chloroform and 1 volume glacial acetic acid) the number and area of all visible tumours was scored using a dissection microscope at $10 \times$ magnification.

For examination of tumour pathology, "gut roll" preparations were made from mice with overt signs of neoplasia as described above, fixed in $10 \%$ buffered formalin, wax embedded, and stepped serial sections stained with haematoxylin and eosin. Mitotic and apoptotic counts were defined as the mean number of mitotic or apoptotic figures in a single high-power ( $\times$ 400) microscope field within each of ten adenomas of the small intestine of comparable size and dysplasia in preparations from five or six individual mice (of both sexes combined) of each genotype, counting only intra-epithelial figures and avoiding debris in glandular lumina and any non-neoplastic epithelium on the adenoma surface.

Tumour number, area, and mitotic and apoptotic counts were compared by Student's $t$-test.

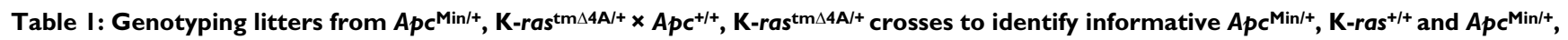
K-ras ${ }^{\mathrm{tm}} \triangle 4 \mathrm{~A} / \mathrm{tm} \triangle 4 \mathrm{~A}$ offspring

\begin{tabular}{|c|c|c|c|}
\hline Genotype & Apc & neo & K-ras exon 4A \\
\hline Apc $\mathrm{Min} /+, \mathrm{K}-\mathrm{ras}^{+/+}$ & + (I23 bp, I44 bp) & - & + (72 bp) \\
\hline$A p c^{\mathrm{Min} /+}, \mathrm{K}-\mathrm{ras}^{\mathrm{tm} \Delta 4 \mathrm{~A} /+}$ & + (I 23 bp, I44 bp) & $+(206$ bp) & + (72 bp) \\
\hline$A p c^{\operatorname{Min} /+}, \mathrm{K}-r a s^{\mathrm{tm} \Delta 4 \mathrm{~A} / \mathrm{tm} \Delta 4 \mathrm{~A}}$ & $+(123$ bp, I44 bp) & $+(206$ bp) & - \\
\hline $\mathrm{Apc}^{+/+}, \mathrm{K}-\mathrm{ras}^{+/+}$ & $+(123 \mathrm{bp})$ & - & + (72 bp) \\
\hline$A p c^{+/+}, \mathrm{K}-\mathrm{ras}^{\mathrm{tm} \Delta 4 \mathrm{~A} /+}$ & $+(123$ bp) & $+(206$ bp) & $+(72$ bp) \\
\hline 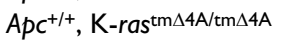 & $+(123$ bp $)$ & $+(206$ bp) & - \\
\hline
\end{tabular}

+/- = PCR product present/absent respectively (see Methods) 


\section{Analysis of K-ras mutations by PCR-direct sequencing}

DNA was prepared from individual tumours dissected from the small intestine and screened for the presence of K-ras mutations at codons 12,13 and 61 as described previously [20].

\section{Analysis of $K$-ras 4A and K-ras 4B transcript expression levels by quantitative $R T-P C R$}

Normal small intestinal tissue samples and tumours (at least $2 \mathrm{~mm}$ diameter, from mice with overt signs of neoplasia as described above, care being taken to avoid Peyer's patches) were dissected and frozen in "RNA later" buffer (Sigma) for subsequent RNA extraction. Total RNA (100 ng) was reverse transcribed in $25 \mu$ l volume using the iTaq SYBR Green RT-PCR kit (Bio-Rad) following the manufacturer's instructions. All real-time quantitative reverse transcription polymerase chain reactions (RTqPCR) were amplified starting with denaturation at $95^{\circ} \mathrm{C}$ for $3 \mathrm{~min}$, then 45 cycles of $95^{\circ} \mathrm{C}$ for $15 \mathrm{sec}$ and $60^{\circ} \mathrm{C}$ for $1 \mathrm{~min}$. The following exon-spanning primers were used: mouse $\beta$-actin upstream primer ( 5 '-AAGCTGTGCTATGTTGCTCTAGACT-3'), and downstream primer (5'-CACTTCATGATGGAATTGAATGTAG-3'); mouse K-ras 4A upstream primer (5'-CCTGGTAGGGAATAAGTGTGATTTG-3'), and downstream primer (5'-GTACTGTCGGATCTCTCTCACCAAT-3'); mouse K-ras 4B upstream primer (5'-GAGTAAAGGACTCTGAAGATGTGCC-3') located in K-ras exon 3, and downstream primer (5'CATCGTCAACACCCTGTCTTGTCTT-3') that spans the junction of K-ras exon 3 and 4B (specific for the mouse Kras $4 \mathrm{~B}$ transcript). The PCR product sizes derived from $\mathrm{K}$ ras $4 \mathrm{~A}, \mathrm{~K}$-ras $4 \mathrm{~B}$ and $\beta$-actin transcripts were $185 \mathrm{bp}, 158$ bp and 148 bp respectively. The specificities of the PCR reactions were confirmed by dissociation curve analysis and 2\% agarose gel electrophoresis. All PCR products were analysed when in the exponential phase of PCR amplification. Quantification of the relative expression levels of K-ras 4A and K-ras 4B transcripts was performed using standard curves with normalization against those of $\beta$-actin transcripts from the same sample. The relative values were corrected for dilution factors and then corrected for the differences in size of $4 \mathrm{~A}$ and $4 \mathrm{~B}$ amplified products. Because the DNA binding affinities of the PCR primers and the sizes of the amplified products were closely similar for the K-ras 4A and K-ras 4B PCR reactions, and the standard curves also showed that the PCR efficiencies for the K-ras 4A and K-ras 4B PCR reactions were very similar at $74.8 \%$ and $76.1 \%$ respectively, the expression levels of these two different transcripts, K-ras $4 \mathrm{~A}$ and K-ras $4 \mathrm{~B}$, can be compared relative to each other, setting the level of expression of K-ras 4A in wild-type C57BL/6 mouse lung as an arbitrary value of 1.0 .

\section{Results}

Both K-ras splice variants are expressed in mouse small intestine $[18,24]$. In the present study the relative levels of the K-ras $4 \mathrm{~A}$ and $4 \mathrm{~B}$ transcripts were quantified by realtime RT-qPCR analysis. Min mice were examined at 8 weeks-old before they showed any visible sign of intestinal tumorigenesis and, for control purposes, comparisons were made with age-matched wild-type mice. The K-ras 4A/4B transcript ratio did not differ significantly $(P=$ $0.95)$ between wild-type $(1.07 \pm 0.09)$ and Min $(1.07 \pm$ $0.15)$ mice, and in both cases the K-ras $4 \mathrm{~A}$ transcript accounted for about $50 \%$ of K-ras expressed in the small intestine (Figure 1).

The reduced K-ras 4A/4B splice variant ratio in sporadic human CRC involves down-regulation of K-ras 4A expression [11]. In Min mice (Figure 2), while there was no significant difference between K-ras $4 \mathrm{~A}$ and $4 \mathrm{~B}$ transcript

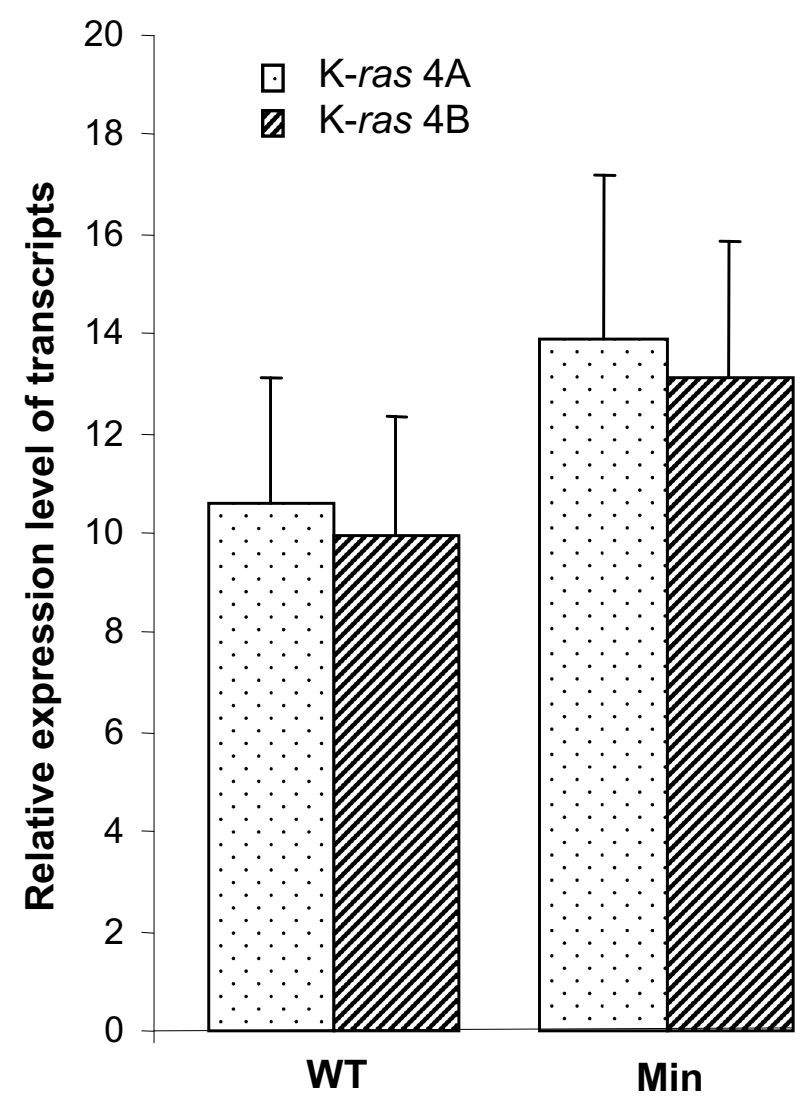

Figure I

Real-time $R T$-qPCR analysis showing relative expression of the K-ras 4A and 4B transcripts (mean \pm SD) in small intestine (duodenum) from 8 week-old, inbred (C57BL/6) wild-type (WT) and $\mathrm{Apc}$ Min/+ (Min) mice (6 male mice were analysed in each cohort). Light (stippled) bars, K-ras 4A; dark (hatched) bars, K-ras 4B. 
levels in normal small intestine $(P=0.383)$, tumours of the small intestine showed significantly reduced levels of $\mathrm{K}$-ras 4A relative to K-ras 4B transcripts $(P=0.0015)$. However, the reduced K-ras $4 \mathrm{~A} / 4 \mathrm{~B}$ splice ratio was due to an increase in the level of K-ras 4B transcript expression, while the level of K-ras 4A transcripts was not appreciably altered. While this provides no support for the hypothesis that K-ras 4A plays a role in modulating intestinal tumorigenesis, it does not exclude this hypothesis, which is worthy of further examination given the high expression levels and established pro-apoptotic action of K-ras 4A in mouse intestine and the antagonistic effects of the $4 \mathrm{~A}$ and $4 \mathrm{~B}$ isoforms [16]. Therefore, to determine if the K-Ras 4A proto-oncoprotein can modulate tumorigenesis in the small intestine comparisons were made between agematched $A p c^{\mathrm{Min} /+}$, K-ras ${ }^{+/+}$and $A p c^{\mathrm{Min} /+}$, K-ras ${ }^{\mathrm{tm}} \Delta 4 \mathrm{~A} / \mathrm{tm} \Delta 4 \mathrm{~A}$ mice. Since gender may influence tumour development in the Min mouse [see [25]] males and females were considered separately. Mice were sampled randomly from the stock at 106 days when the stock was outwardly healthy, and at 152 days when $17 \%(19 / 112)$ of the stock had been either found dead or necessitated necropsy due to sickness [20\% (12/59)Apc $\mathrm{Min} /+$, K-ras ${ }^{++}$and 13\% (7/53) $\left.A p c^{\mathrm{Min} /+}, \mathrm{K}-\mathrm{ras}{ }^{\mathrm{tm} \Delta 4 \mathrm{~A} / \mathrm{tm} \Delta 4 \mathrm{~A}}\right]$. Examination of the small intestine revealed a similar overall tumour number, and no difference in tumour size for both male and female mice at either time point (Table 2). Histological analysis of intestinal preparations from $A p c^{\mathrm{Min} /+}, \mathrm{K}_{-} \mathrm{ras}^{+/+}(n=8)$ and $A p c$ $\mathrm{Min} /+$, K-ras ${ }^{\mathrm{tm} \triangle 4 \mathrm{~A} / \mathrm{tm} \Delta 4 \mathrm{~A}}(n=7)$ mice with overt signs of neoplasia revealed that all tumours from both genotypes were adenomas of similar, mild to moderate, dysplasia, with no evidence of invasive carcinoma in any of them. There was no statistically significant difference between the genotypes in mitotic counts $\left(A p c^{\mathrm{Min} /+}, \mathrm{K}_{-\mathrm{ras}^{+/+}}: 25.3\right.$;

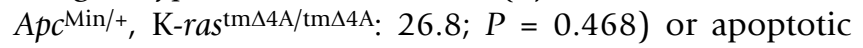
counts (both genotypes: $2.1 ; P=1.0$ ) in the tumours.
Consistent with the tumour data $A p c^{\mathrm{Min} /+}, \mathrm{K}-\mathrm{ras}^{+/+}$and $A p c$ Min/+, K-ras ${ }^{\mathrm{tm}} \Delta 4 \mathrm{~A} / \mathrm{tm} \Delta 4 \mathrm{~A}$ mice exhibited similar survival (Figure 3$)$ for both males $\left(\chi^{2}{ }_{1}=1.91, \mathrm{P}=0.167\right)$ and females $\left(\chi^{2}{ }_{1}=0.44, \mathrm{P}=0.506\right)$.

Previous studies have established that intestinal tumours from Apc mutant mice, including adenocarcinomas, do not harbour K-ras activating mutations [20,26,27]. In confirmation, and to establish this applies in compound mutant Min mice, K-ras codons 12, 13 and 61 were sequenced in 27 small intestinal tumours, that included 8 tumours from ApcMin/+, K-ras+/+ mice, 15 tumours from ApcMin/+, K-rastm $\Delta 4 \mathrm{~A} /+$ mice, and 4 tumours from Apc$\operatorname{Min} /+$, K-rastm $\Delta 4 \mathrm{~A} / \operatorname{tm} \Delta 4 \mathrm{~A}$ mice. No tumours were found to harbour a K-ras activating mutation (data not shown).

\section{Discussion}

Because intestinal tumours develop spontaneously in Apc mutant mice they present a powerful model system to study factors that modulate intestinal tumour development, including genetic modifiers, which may be important in the design of potential therapeutic strategies [reviewed [28]]. To date, inactivating mutations in genes involved in arachidonic acid and sphingosine metabolism, DNA methylation, and genes encoding the matrix mellalloproteinase MMP-7, VEGF-A and matricellular proteins have been found to suppress intestinal tumorigenesis in $A p c$ mutant mice. Conversely, inactivating mutations in genes related to genomic stability and DNA mismatch repair, and genes that regulate PI3-K/AKT signalling, and proliferation and differentiation in the cryptvillus axis, promote tumorigenesis [see [19,25,28-38]].

Because homozygosity for the K-ras null allele is embryonic lethal [39] nothing is known about the effect of inactivation of the K-ras proto-oncogene on intestinal

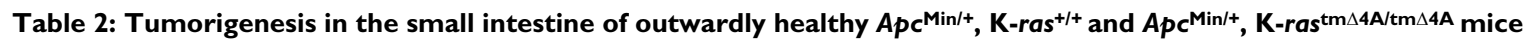

\begin{tabular}{|c|c|c|c|c|c|}
\hline Genotype & Sex & Mice per cohort & Age (days) \pm SEM & Tumour number \pm SEM & Tumour area $\left(\mathrm{mm}^{2}\right) \pm$ SEM \\
\hline \multicolumn{6}{|c|}{ Stocks culled at $\cong 106$ days } \\
\hline Apc $\mathrm{Min} /+, \mathrm{K}-\mathrm{ras}^{+/+}$ & M & 4 & $108.3 \pm 1.0$ & $36.3 \pm 7.9 a$ & $43.5 \pm 9.4^{i}$ \\
\hline$A p c^{M i n /+}, \mathrm{K}_{- \text {ras }^{+/+}}$ & $\mathrm{F}$ & 4 & $104.5 \pm 1.5$ & $59.0 \pm 2.9 b$ & $74.3 \pm 8.8$ \\
\hline$A p c^{\mathrm{Min} /+}, \mathrm{K}-\mathrm{ras}^{\mathrm{tm} \Delta 4 \mathrm{~A} / \mathrm{tm} \Delta 4 \mathrm{~A}}$ & $M$ & 6 & $107.2 \pm 0.5$ & $51.5 \pm 16.2^{c}$ & $68.8 \pm 23.1^{k}$ \\
\hline 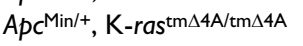 & $\mathrm{F}$ & 4 & $105.5 \pm 0.5$ & $36.5 \pm 15.3^{d}$ & $57.0 \pm 29.8^{\prime}$ \\
\hline \multicolumn{6}{|c|}{ Stocks culled at $\cong 152$ days } \\
\hline Apc Min/+, K-ras ${ }^{+/+}$ & $M$ & 10 & $152.0 \pm 0.9$ & $56.8 \pm 8.8 \mathrm{e}$ & $131.0 \pm 19.6^{m}$ \\
\hline$A p c^{\mathrm{Min} /+}, \mathrm{K}-\mathrm{ras}^{+/+}$ & $\mathrm{F}$ & 4 & $151.8 \pm 1.3$ & $46.3 \pm 5.9 f$ & $89.8 \pm 10.9^{n}$ \\
\hline$A p c^{\operatorname{Min} /+}, \mathrm{K}-\mathrm{ras}^{\mathrm{tm} \Delta 4 \mathrm{~A} / \mathrm{tm} \Delta 4 \mathrm{~A}}$ & $M$ & 3 & $153.3 \pm 1.3$ & $35.3 \pm 7.5 \mathrm{~g}$ & $99.0 \pm 20.0^{\circ}$ \\
\hline$A p c^{\mathrm{Min} /+}, \mathrm{K}-\mathrm{ras}^{\mathrm{tm} \Delta 4 \mathrm{~A} / \mathrm{tm} \Delta 4 \mathrm{~A}}$ & $\mathrm{~F}$ & 9 & $|5| . \mid \pm 2.8$ & $61.3 \pm 9.7^{h}$ & $118.7 \pm 22.3 p$ \\
\hline
\end{tabular}

M, male; $F$, female. ${ }^{a}$ vs. $c P=0.42 ; b$ vs. ${ }^{d} P=0.20$; e vs. $g P=0.090 ; f v s .{ }^{h} P=0.21 ;{ }^{i}$ vs. ${ }^{k} P=0.34$;

${ }^{j}$ vs. ${ }^{\prime} P=0.60 ;{ }^{m}$ vs. ${ }^{\circ} P=0.28 ;{ }^{n}$ vs. ${ }^{P} P=0.27$ (Student's t-test in each case). 


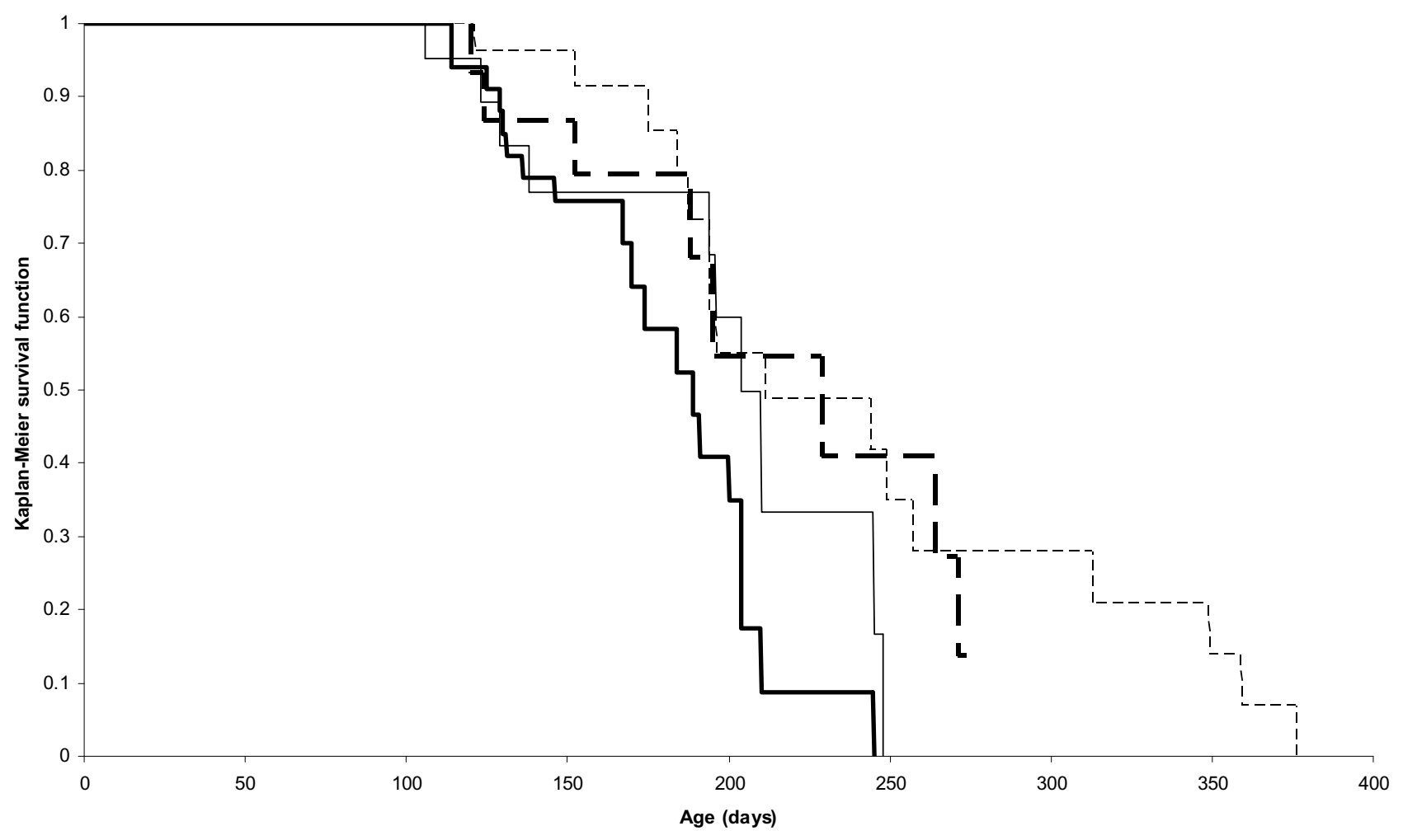

Figure 3

Survival curve showing ApcMin/+, K-ras ${ }^{+/+}$mice $[n=20$ males (heavy continuous line), $n=8$ females (heavy broken line)] and $A$ p $^{\mathrm{Min} /+}$, K-ras ${ }^{\mathrm{tm}} \triangle 4 \mathrm{~A} / \mathrm{tm} \Delta 4 \mathrm{~A}$ mice [ $\mathrm{n}=10$ males (light continuous line), $n=16$ females (light broken line)]. In each case $n$ refers to the number of uncensored observations.

homeostasis. The present study found the K-Ras 4A protooncoprotein, whose transcript accounts for some $50 \%$ of K-ras expressed in the small intestine, does not affect tumour development in the Min mouse intestine where tumours lack K-ras activating mutations. The result is perhaps unexpected given that the K-ras proto-oncogene can promote ES cell differentiation, exert a pro-apoptotic action in ES cells following DNA damage induced by etoposide or cisplatin $[16,40,41]$ and, importantly, can suppress tumour development in the absence [41] as well as the presence [42] of its oncogenic allele. Moreover, the K-Ras 4A proto-oncoprotein exerts a pro-apoptotic action in both ES cells and mouse small intestine following etoposide-induced DNA damage [16]. The failure of K-Ras $4 \mathrm{~A}$ to affect tumorigenesis may reflect the fact that K-Ras $4 \mathrm{~A}$ deficiency does not affect baseline levels of apoptosis in the crypt [16] and/or abolish completely the apoptotic response in the small intestine following DNA damage, but rather it is reduced and delayed, which implies activation of K-Ras 4A-independent apoptotic pathways. The complex relationship between apoptosis and cancer development is highlighted by recent evidence that the tumour suppressor activity of $p 53$ in radiation-induced lymphoma is not dependent on its ability to promote apoptosis and so eliminate mutant cells [43]. Therefore, the K-Ras 4A-mediated pro-apoptotic response in the small intestine following etoposide-induced DNA damage could be irrelevant for tumour formation and, indeed, it does not necessarily follow that K-Ras $4 \mathrm{~A}$ has a proapoptotic action at physiological levels of DNA damage, or with other types of DNA damage. Thus, while the pattern of K-ras 4A expression is strongly conserved in human and mouse tissues $[12,18]$ its role in intestinal homeostasis remains unclear. However, given that K-Ras 4B can promote ES cell differentiation and suppress mammary carcinogenesis in the absence of its oncogenic allele $[16,44]$ it remains to be determined whether K-Ras $4 \mathrm{~B}$ can suppress intestinal tumorigenesis. This would necessitate a comparison between $A p c^{\mathrm{Min} /+}$ mice that can, and cannot, express K-ras 4B. However, since K-ras is essential for mouse development [39] and K-ras 4B is the major splice variant and, unlike K-ras $4 \mathrm{~A}$, is expressed ubiquitously $[12,18]$, it is doubtful that K-Ras 4B-deficient mice would 


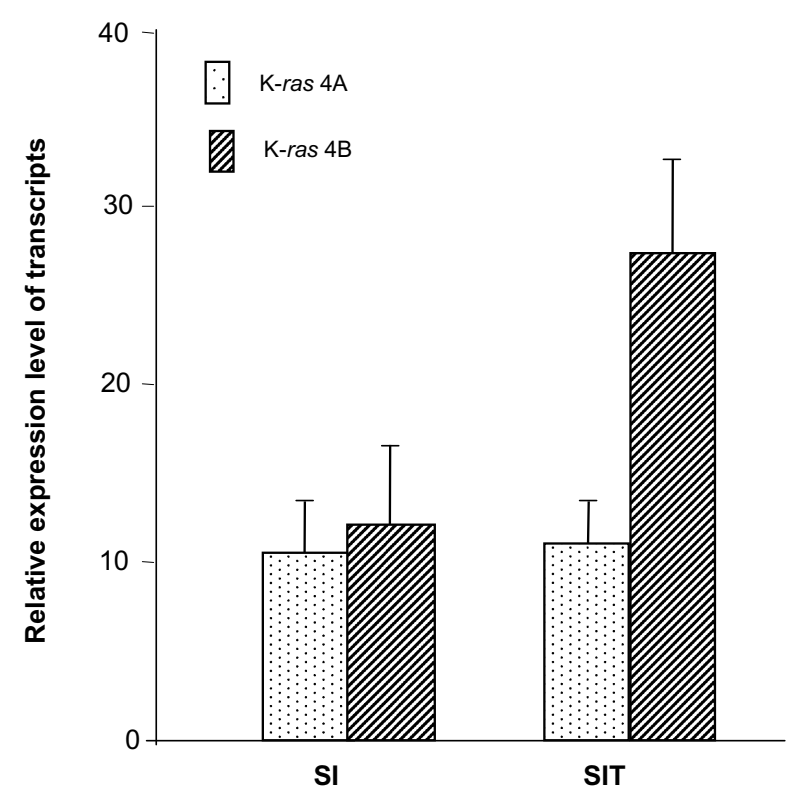

Figure 2

Real-time RT-qPCR analysis showing relative expression of the K-ras 4A and 4B transcripts (mean \pm SD of 6 samples in each case) in normal small intestine (SI) and tumours of the small intestine (SIT) of ApcMin/+ mice with overt signs of neoplasia. Light (stippled) bars, K-ras 4A; dark (hatched) bars, K-ras 4B.

be viable, and therefore such a study would require conditional inactivation.

In sporadic CRC the K-ras $4 \mathrm{~A} / 4 \mathrm{~B}$ splice variant ratio is reduced in colon cancer cell lines, regardless of whether they harbour K-ras activating mutations [11,12]. Since the $\mathrm{K}$-ras $4 \mathrm{~A} / 4 \mathrm{~B}$ ratio is reduced in primary CRC tumours [12] the altered ratio in cell lines, including those that lack Kras activating mutations, is more likely to be symptomatic of the tumours from which they were derived rather than an in vitro artefact of the growth conditions. While altered splicing of the K-ras proto-oncogene in favour of K-ras 4B could, conceivably, modulate tumour progression, and possibly by effects on MMP-2 expression, apoptosis and/ or differentiation (see Background), the present study found that alteration in the ratio of the K-Ras proto-oncoproteins in favour of K-Ras 4B (by targeted deletion of Kras exon 4A) does not affect mouse survival or tumour number, size or histopathology (including mitotic and apoptotic counts). These observations are unlikely to reflect the fact that Min mice die before intestinal tumours can progress, since adenocarcinomas do develop in compound mutant Min mice [see [19,29-31,36]]. They could relate to the fact that the altered ratio in human CRC involves not only an decrease in K-ras $4 \mathrm{~A}$ expression but also an increase in K-ras 4B expression [11]: indeed, in
Min mouse tumours, K-ras 4B expression is elevated while K-ras 4A expression is not appreciably altered. K-ras 4B expression was unaffected in the comparisons shown in Table 2 and Figure 3 because K-ras 4A deficiency does not affect K-ras 4B expression in the small intestine [16]. Given that K-ras 4B, unlike K-ras 4A, can promote cell migration and MMP2 expression $[10,15]$, the possibility that increased expression of K-ras $4 \mathrm{~B}$, with or without reduced expression of K-ras $4 \mathrm{~A}$, is an essential component for tumour progression in cases that lack K-ras activating mutations remains to be addressed. Although the present study establishes that a reduction in the K-ras $4 \mathrm{~A} / 4 \mathrm{~B}$ ratio does not affect $A p c$-driven intestinal tumorigenesis per se the finding that the ratio is reduced in Min adenomas that lack K-ras activating mutations raises the intriguing possibility that K-ras may have a more widespread role in tumorigenesis in addition to that in lung, colon and pancreatic cancers that normally harbour K-ras activating mutations [reviewed [6]]. Thus, given that K-ras 4A and 4B are co-expressed widely in mammalian tissues $[12,18]$ it remains to be determined whether their ratio is altered in other types of tumours that routinely lack K-ras activating mutations.

\section{Conclusion}

Even though the K-Ras 4A proto-oncoprotein exerts a proapoptotic action in the small intestine following etoposide-induced DNA damage, it does not affect tumour development, albeit when expressed in the absence of its oncogenic allele.

\section{Competing interests}

The authors declare that they have no competing interests.

\section{Authors' contributions}

CEP, study design, performed experimental studies, drafted the manuscript; MJA \& FL, real-time RT-qPCR analysis, histopathology, edited the manuscript; LR, MW, PSD, RLB, NJL \& RAR, mouse breeding, genotyping and tumour studies; OJS, contribution to study design, provision of cDNAs, edited the manuscript; MLH, statistical analysis, edited the manuscript. All authors read and approved the final manuscript.

\section{Acknowledgements}

The study was supported by Cancer Research UK (CUK) Project grant C5/ A43 18 awarded to C.E.Patek, D.J.Harrison and M.L.Hooper. We are grateful to Alan Clarke for helpful discussion.

\section{References}

I. Jas JR: Colorectal cancer: a multipathway disease. Crit Rev Oncog 2006, I 2:273-287.

2. Srebrow A, Kornblihtt AR: The connection between splicing and cancer. J Cell Sci 2006, I 1 9:2635-264I.

3. Venables JP: Unbalanced alternative splicing and its significance in cancer. Bioessays 2006, 28:378-386.

4. Gardina PJ, Clark TA, Shimada B, Staples MK, Yang Q, Veitch J, Schweitzer A, Awad T, Sugnet C, Dee S, Davies C, Williams A, Turpaz Y: 
Alternative splicing and differential gene expression in colon cancer detected by a whole genome exon array. BMC Genomics 2006, 7:325-43.

5. Skotheim RI, Nees M: Alternative splicing in cancer: Noise, functional, or systematic ? Int J Biochem Cell Biol 2007, 39:1432-1449.

6. Malumbres M, Barbacid M: RAS oncogenes: the first $\mathbf{3 0}$ years. Nat Rev Cancer 2003, 3:459-465.

7. Li B-H, Zhao P, Liu S-Z, Yu Y-M, Han M, Wen J-K: Matrix metalloproteinase-2 and tissue inhibitor of metalloproteinase- 2 in colorectal carcinoma invasion and metastasis. World J Gastroenterol 2005, II:3046-3050.

8. Pollock CB, Shirasawa S, Sasasuki T, Kolch W, Dhillon AS: Oncogenic K-RAS is required to maintain changes in cytoskeleta organization, adhesion, and motility in colon cancer cells. Cancer Res 2005, 65: 1244-1250.

9. Smakman N, Borel Rinkes IH, Voest EE, Kranenburg O: Control of colorectal metastasis formation by K-Ras. Biochim Biophys Acta 2005, 1756:103-II4.

10. Voice JK, Klemke RL, Le A, Jackson JH: Four human ras homologs differ in their abilities to activate Raf-I, induce transformation, and stimulate cell motility. I Biol Chem 1999, 274: $17164-17 \mid 70$

11. Butz JA, Roberts KG, Edwards JS: Detecting changes in the relative expression of KRAS2 splice variants using polymerase colonies. Biotechnol Prog 2004, 20: 1836-1839.

12. Plowman SJ, Berry RL, Bader SA, Luo F, Arends MJ, Harrison DJ, Hooper ML, Patek CE: K-ras 4A and 4B are co-expressed widely in human tissues, and their ratio is altered in sporadic colorectal cancer. J Exp Clin Cancer Res 2006, 25:259-267.

13. Fisher GH, Wellen SL, Klimstra D, Lenczowski JM, Tichelaar JW, Lizak MJ, Whitsett JA, Koretsky A, Varmus HE: Induction and apoptotic regression of lung adenocarcinomas by regulation of a $K$-Ras transgene in the presence and absence of tumour suppressor genes. Genes Develop 200I, 15:3249-3262.

14. Ji H, Wang Z, Perera S, Li D, Liang M-C, Zaghlul S, McNamara K, Chen L, Albert M, Sun Y, Al-Hashem R, Chirieac LR, Padera R, Bronson RT, Thomas RK, Garraway LA, Janne PA, Johnson BE, Chin L, Wong K-K: Mutations in BRAF and KRAS converge on activation of the mitogen-activated protein kinase pathway in lung cancer mouse models. Cancer Res 2007, 67:4933-4939.

15. Liao J, Wolfman JC, Wolfman A: K-Ras regulates the steady-state expression of matrix metalloproteinase $\mathbf{2}$ in fibroblasts. J Biol Chem 2003, 278:3187I-3I878.

16. Plowman SJ, Arends MJ, Brownstein DG, Luo F, Devenney PS, Rose L, Ritchie A-M, Berry RL, Harrison DJ, Hooper ML, Patek CE: The KRas 4A isoform promotes apoptosis but does not affect either lifespan or spontaneous tumor incidence in aging mice. Exp Cell Res 2006, 3 12:16-26.

17. Burdon T, Smith A, Savatier P: Signalling, cell cycle and pluripotency in embryonic stem cells. Trends Cell Biol 2002, I 2:432-438.

18. Plowman SJ, Williamson DJ, O'Sullivan MJ, Doig J, Ritchie A-M, Harrison DJ, Melton DW, Arends MJ, Hooper ML, Patek CE: While K-ras is essential for mouse development, expression of the K-ras 4A splice variant is dispensable. Mol Cell Biol 2003, 23:9245-9250

19. Yamada Y, Mori H: Multistep carcinogenesis of the colon in ApcMin/+ mouse. Cancer Sci 2007, 98:6-10.

20. Shoemaker AR, Luongo C, Moser AR, Marton LJ, Dove WF: Somatic mutational mechanisms involved in intestinal tumor formation in Min mice. Cancer Res 1997, 57:1999-2006.

21. [http://www.informatics.jax.org/searches/probe.cgi?37/39]

22. Luongo C, Moser AR, Gledhill S, Dove WF: Loss of Apc in intestinal adenomas from Min mice. Cancer Res 1994, 54:5947-5952.

23. Lee ET: Statistical Methods for Survival Data Analysis 2nd edition. Wiley: New York; 1992.

24. Pells S, Divjak M, Romanowski P, Impey H, Hawkins NJ, Clarke AR, Hooper ML, Williamson DJ: Developmentally-regulated expression of murine K-ras isoforms. Oncogene 1997, 15:1781-1786.

25. McAlpine CA, Barak Y, Matise I, Cormier RT: Intestinal-specific PPAR $\gamma$ deficiency enhances tumorigenesis in the Apc Min/+ mice. Int J Cancer 2006, I I 9:2339-2346.

26. Smits R, Kartheuser A, Jasgmohan-Ahangur S, Leblanc V, Breukel C, de Vries A, van Kranen $H$, van Kriecken JH, Williamson S, Edelmann W, Kucherlapati R, Khan P.M, Fodde R: Loss of Apc and the entire chromosome 18 but absence of mutations at the Ras and
Tp53 genes in intestinal tumors from $A p c 1638 \mathrm{~N}$, a mouse model for Apc-driven carcinogenesis. Carcinogenesis 1997, I8:321-327.

27. Tanaka T, Kohno H, Suzuki R, Hata K, Sugie S, Niho N, Sakano K, Takahashi M, Wakabayashi K: Dextran sodium sulfate strongly promotes colorectal carcinogenesis in $\mathrm{Apc}(\mathrm{Min} /+)$ mice: inflammatory stimuli by dextran sodium sulfate results in development of multiple colonic neoplasms. Int J Cancer 2006, I I 8:25-34.

28. Taketo MM: Mouse models of gastrointestinal tumors. Cancer Sci 2006, 97:355-361.

29. Halberg RB, Katzung DS, Hoff PD, Moser AR, Cole CE, Lubet RA Donehower LA, Jacoby RF, Dove WF: Tumorigenesis in the multiple intestinal neoplasia mouse: redundancy of negative regulators and specifically of modifiers. Proc Natl Acad Sci USA 2000, 97:346I-3466.

30. Batlle E, Bacani J, Begthel H, Jonkheer S, Gregorieff A, Born M van de, Malats N, Sancho E, Boon E, Pawson T, Gallinger S, Pals S, Clevers H: EphB receptor activity suppresses colorectal cancer progression. Nature 2005, 435: I I 26- I I30.

3I. Rao CV, Yang TM, Swamy MV, Liu T, Fang Y, Mahmood R, JhanwarUniyal M, Dai W: Colonic tumourigenesis in BubRI/ApcMin/+ compound mutant mice is linked to premature separation of sister chromatids and enhanced genomic instability. Proc Natl Acad Sci USA 2005, 102:4365-4370.

32. Kohno M, Momoi M, Oo ML, Paik J-H, Lee Y-M, Venkataraman K, A Y, Ristimaki AP, First H, Sano H, Rosenberg D, Saba JD, Proia R, Hla $\mathrm{T}$ : Intracellular role for sphingosine kinase $\mathrm{I}$ in intestinal adenoma cell proliferation. Mol Cell Biol 2006, 26:72 I I-7223.

33. Prokhortchouk A, Sansom O, Selfridge J, Caballero IM, Salozhin S, Aithozhina D, Cerchietti L, Meng FG, Augenlicht LH, Mariadason JM, Hendrich B, Melnick A, Prokhortchouk E, Clarke A, Bird A: Kaisodeficient mice show resistance to intestinal cancer. Mol Cell Biol 2006, 26:199-208.

34. Sansom OJ, Mansergh FC, Evans MJ, Wilkins JA, Clarke AR: Deficiency of SPARC suppresses intestinal tumorigenesis in APCMin/+ mice. Gut 2007, 56:14|0-|4|4

35. Korsisaar N, Man IM, Forrest WF, Pal N, Bai W, Fuh G, Peale FV, Smits R, Ferrara N: Inhibition of VEGF-A prevents the angiogenic switch and results in increased survival of $\mathrm{Apc}^{+/ \mathrm{Min}}$ mice. Proc Natl Acad Sci USA 2007, 104: 10625-10630.

36. Shao J, Washington MK, Saxena R, Sheng H: Heterozygous disruption of the PTEN promotes intestinal neoplasia in APCMin/+ mouse: roles of osteopontin. Carcinogenesis 2007, 28:2476-2483.

37. Kwong LN, Weiss KR, Haigis KM, Dove WF: Atm is a negative regulator of intestinal neoplasia. Oncogene 2008, 27:1013-1018.

38. Li P, Schulz S, Bombonati A, Palazzo JP, Hyslop TM, Xu Y, Baran AA, Siracusa LD, Pitari GM, Waldman SA: Guanylyl cyclase C suppresses intestinal tumorigenesis by restricting proliferation and maintaining genomic integrity. Gastroenterology 2007, 133:599-607.

39. Johnson L, Greenbaum D, Cichowski K, Mercer K, Murphy E, Schmitt E, Bronson RT, Umanoff H, Edelmann W, Kucherlapati R, Jacks T: Kras is an essential gene in the mouse with partial functional overlap with N-ras. Genes Dev 1997, I I:2468-248I

40. Brooks DJ, James RM, Patek CE, Williamson J, Arends MJ: Mutant Kras enhances apoptosis in embryonic stem cells in combination with DNA damage and is associated with increased levels of pl9 (ARF). Oncogene 200I, 20:2। 44-2। 52.

4I. James RJ, Arends MJ, Plowman SJ, Brooks DG, Miles CG, West JD, Patek CE: K-ras proto-oncogene exhibits tumour suppressor activity as its absence promotes tumorigenesis in murine teratomas. Mol Cancer Res 2003, I:820-825.

42. Zhang Z, Wang Y, Vikis HG, Johnson L, Liu G, Li J, Anderson MW, Sills RC, Hong HL, Devereux TR, Jacks T, Guan K-L, You M: Wildtype Kras 2 can inhibit lung carcinogenesis in mice. Nature Genet 200I, 29:25-33.

43. Christophorou MA, Ringshausen I, Finch AJ, Swigart LB, Evan GI: The pathological response to DNA damage does not contribute to p53-mediated tumour suppression. Nature 2006, 443:2। 4-2I7.

44. Thompson TA, Hag JD, Lindstrom MJ, Griep AE, Lohse JK, Gould $M N$ : Decreased susceptibility to MNU-induced mammary carcinogenesis in transgenic rats carrying multiple copies of a rat ras gene driven by the Harvey ras promoter. Oncogene 2002, 21 :2797-2804. 


\section{Pre-publication history}

The pre-publication history for this paper can be accessed here:

http://www.biomedcentral.com/1471-230X/8/24/pre

pub

Publish with Bio Med Central and every scientist can read your work free of charge

"BioMed Central will be the most significant development for disseminating the results of biomedical research in our lifetime. " Sir Paul Nurse, Cancer Research UK

Your research papers will be:

- available free of charge to the entire biomedical community

- peer reviewed and published immediately upon acceptance

- cited in PubMed and archived on PubMed Central

- yours - you keep the copyright 